\title{
Miten käsitteellistää ammatillista toimijuutta työssä?
}

\begin{abstract}
$y$
Artikkelissa tarkastellaan, miten toimijuus on ymmärretty

monitieteisessä keskustelussa. Lisäksi pohditaan, miten

ammatillista toimijuutta työssä tulisi käsitteellistää.
\end{abstract}

\section{TARVE KESKUSTELLA AMMATILLISESTA TOIMIJUUDESTA}

TYÖELÄMÄÄ KOSKEVASSA ajankohtaisessa keskustelussa ammatillinen toimijuus (engl. professional agency) korostuu monella tapaa. Työelämässä toimijuus on liitetty perinteisesti rakenteelliseen vallankäyttöön, mutta myös vähemmän näkyviin sosiaalisiin suhteisiin, puhetapoihin ja ihmisten väliseen vuorovaikutukseen kytkeytyvään epäviralliseen valtaan. Silloin kun toimijuutta on tarkasteltu ammatillisena toimijuutena, se on liitetty työntekijöiden vaikutusmahdollisuuksiin ja vastarintaan, mutta myös luovuuteen, motivaatioon ja työkäytäntöjen kehittämiseen.

Työntekijöiltä vaaditaan jatkuvaa tietojen ja taitojen kehittämistä sekä ammatillisten identiteettien tuunausta. Työn arjessa odotetaan uusien työroolien omaksumista ja vastuiden ottamista, perinteisten ammatillisten rajojen ylittämistä ja työurien pitkäjänteistä rakentamista. Työyhteisöiltä edellytetään työkäytäntöjen muutoksia esimerkiksi uuden teknologian käyttöönoton myötä sekä yhteistoiminnallisten ja moniammatillisten työtapojen kehittämistä. Työorganisaatioiden tuottavuuden parantamiseen pyritään rakenteellisten muutosten ja työkulttuurien kehittämisen sekä entistä paremman johtamisen avulla. Näitä pyrkimyksiä yhdistää tarve vahvistaa erilaista ja eritasoista ammatillista toimijuutta työssä.

Kasvatuksessa ja aikuiskasvatuksessa toimijuuden idea ei ole uusi. Se on löydettävissä jo Valistuksen kasvatusta koskevasta ideasta, jonka mukaan ihmisen järjellisen kapasiteetin lisääminen vahvistaa hänen kykyään tehdä itsenäistä arviointia ja harjoittaa autonomista toimintaa. Mezirovin aikuisten oppimista koskevassa teoriassa oppiminen ymmärretään toimijuutta vahvistavana emansipatorisena voimaan- 
tumisena. Freiren vapautuksen pedagogiikka tähtää yhteisölliseen valtautumiseen ja kollektiivisen toimijuuden vahvistamiseen omien elinolojen parantamiseksi. Viime vuosikymmeninä oppijan aktiivista toimijuutta on korostettu myös konstruktivistisissa oppimisteorioissa. Niissä toimijuuteen on viitattu tiedon aktiivisena rakentamisena sekä metakognitiivisina ja reflektiivisinä prosesseina, jotka edistävät oppijan itsekontrollia ja itseohjausta (esim. Packer \& Goicoechea 2000).

Sosiokulttuurisissa oppimis- ja kehitysteorioissa oppiminen on nähty aktiivisena sosiaalisena osallistumisena ja sen myötä identiteettien rakentamisena ja uudelleen neuvotteluna erilaisissa tietoyhteisöissä (Lave \& Wenger 1991; Wenger 1998). Viime vuosina toimijuuden käsitettä on käytetty lisääntyvästi erityisesti aikuisten oppimista ja kasvua käsittelevässä tieteellisessä keskustelussa (esim. Biesta \& Tedder 2007; Ecclestone 2007; Eteläpelto, Heiskanen \& Collin 2011; Hitlin \& Elder 2007). Myös työssä oppimista ja ammatillisia identiteettejä koskevassa tutkimuksessa toimijuus on noussut keskeiseksi (Billett \& Pavlova 2005; Eteläpelto, Vähäsantanen, Hökkä \& Paloniemi 2014; Fenwick 2006; Hökkä, Eteläpelto \& Rasku-Puttonen 2012; Paloniemi \& Collin 2012; Vähäsantanen \& Eteläpelto 2009; 2011).

Koska toimijuuden käsite on moniselitteinen, tarvitaan rajaavaa ja kohdennettua keskustelua toimijuuden ontologiasta ja sen erilaisista ilmenemismuodoista. Muutoin on vaarana, että toimijuus tieteellisenä käsitteenä liudentuu diffuusiksi ja abstraktiksi yleiskäsitteeksi, jonka merkitys hämärtyy ja menettää ydinsisältönsä. Myös toimijuutta edistävien käytäntöjen sekä sitä vahvistavan pedagogiikan kehittämiseksi tarvitaan keskustelua siitä, mitä toimijuudella tarkoitetaan.

Tässä artikkelissa ${ }^{1}$ luodaan kriittinen katsaus sellaiseen toimijuutta käsittelevään tieteelliseen keskusteluun, jonka on katsottu luovan perustaa ammatillisen toimijuuden käsitteellistämiselle. Tavoitteena on kohdentaa tarkastelu erityisesti siihen, miten toimijuus on ymmärretty erilaisissa toimijuuskäsityksissä, ja tältä pohjalta käsitteellistää ammatillista toimijuutta työssä. Tutkimuskysymykset voidaan täsmentää seuraavasti:
1. Miten toimijuuden ontologinen luonne on erilaisissa toimijuuskäsityksissä ymmärretty?

1.1. Miten diskursiivinen, praktinen ja kehollinen todellisuussuhde on otettu huomioon?

1.2. Miten intentionaalisuus ja temporaa lisuus on otettu huomioon?

1.3. Miten identiteetin merkitys toimijuu delle on ymmärretty?

2. Miten sosiaalisen ja yksilöllisen välinen suhde on erilaissa toimijuuskäsityksissä ymmärretty? Analyysin pohjalta teemme johtopäätöksiä ammatillisen toimijuuden käsitteellistämiseen. Ehdotamme ammatillisen toimijuuden kuvaamiseen subjektikeskeistä, sosiokulttuurista lähestymistapaa.

Jäljitimme aiempaa tutkimusta ja tieteellistä keskustelua toimijuudesta tieteellisestä kirjallisuudesta, erityisesti aikuiskasvatus- ja kasvatustieteiden, mutta myös sosiologian, psykologian ja naistutkimuksen alueilta. Jäljitystä ohjasi myös PROAGENT-hankkeessa (www.jyu.fi/proagent) toimivien kirjoittajien aiempi, lähinnä koulutus- ja terveydenhuoltoalan työntekijöiden ammatilliseen toimijuuteen kohdistunut tutkimus. Tältä pohjalta arvioimme, miten eri tutkimusalueiden keskustelu voisi myötävaikuttaa ammatillisen toimijuuden käsitteellistämiseen. Koska toimijuudesta käytävä keskustelu on monitieteistä, laajaa ja omaa pitkät perinteet erityisesti sosiologiassa, emme tässä artikkelissa pyri tekemään kattavaa analyysiä. Alustavan kartoituksen pohjalta tunnistimme neljä erilaista tutkimustraditiota, joissa toimijuudesta on keskusteltu vilkkaasti: 1. sosiologinen keskustelu, 2. jälkistrukturalistinen naistutkimus, 3. sosiokulttuurinen lähestymistapa ja 4. elämänkulkututkimus.

Kullakin näistä tutkimusalueista on käytetty erilaisia teoreettisia viitekehyksiä, eikä alueelta toiselle ulottuvaa keskustelua ole juuri käyty. Sen sijaan kunkin alueen sisällä on käyty vilkasta sisäistä debattia. Tämän vuoksi on perusteltua tarkastella alueita toisistaan erillisinä. Koska kunkin alueen sisällä on tunnistettavissa hyvinkin erilaisia käsityksiä toimijuuden ontologiasta sekä eroja yksilön ja sosiaalisen välisestä suhteesta, olemme valinneet lopulliseen tarkasteluun kultakin alueelta sellaiset merkittävimmät teoreetikot, 
jotka esittävät toimijuudesta toisistaan poikkeavia käsityksiä käyden kriittistä keskustelua toistensa kanssa.

Seuraavassa tuloksia tarkastellaan tutkimusalueiden mukaisessa järjestyksessä. Tämän jälkeen esitämme yhteenvetotaulukon, johon tiivistämme vastaukset tutkimuskysymyksiin.

\section{SOSIOLOGIT GIDDENS JA ARCHER TOIMIJUUDEN JA RAKENNETEKIJÖIDEN SUHTEESTA}

Yhteiskuntatieteissä keskustelu toimijuudesta on liittynyt keskusteluun rakenteista, diskursseista ja vallasta sekä niiden rajoittavasta, mutta myös resursoivasta vaikutuksesta yksilöiden toimijuuteen. Yleisesti oletetaan, että sellaiset rakennetekijät, kuten sosiaaliluokka, sukupuoli sekä taloudelliset ja ammatilliset olosuhteet, vaikuttavat yksilöiden toimijuuteen. Eroja on lähinnä siinä, kuinka paljon yksilöillä katsotaan olevan toimijuutta. Sosiologisessa toimijuutta koskevassa keskustelussa erityisesti kaksi vaikutusvaltaista teoreetikkoa, Anthony Giddens ja Margaret Archer, ovat käsitelleet laajasti toimijuutta tehden myös ontologiset kannanottonsa selviksi.

Giddensin (1984) näkemyksen mukaan inhimillinen toiminta ilmentää toimijuutta ainoastaan silloin, kun se on toimijan näkökulmasta intentionaalista. Tällöin pelkkä automaattinen, tiedostamaton tai tavan vuoksi tapahtuva reagointi johonkin asiantilaan ei vielä ole toimijuutta. Intentionaalisuus merkitsee sitä, että toimija tietää tai ainakin uskoo, että tekemisellä on tiettyjä tuloksia tai seuraamuksia. Toimijuus on Giddensille toimimista tietoisesti eri tavalla tilanteessa, jossa yksilöllä on vaihtoehtoja ja valtaa toimia toisin ja näin vaikuttaa tapahtumien kulkuun. Giddensin määritelmässä korostuu vahvasti yksilön intentionaalinen rooli tietoisena ja tahtovana toimijana, joka tuottaa ja saa aikaan seuraamuksia yhteisöllisellä ja yhteiskunnallisella tasolla.

Giddensin määritelmää on kritisoitu yksilöllisen ja sosiaalisen analyyttisestä erottamattomuudesta sekä siitä, että se pelkistää inhimillisen elämän puhtaasti yksilön rationaaliseen toimintaan. Ilman yksilöllisen ja sosiaalisen analyyttistä erottamista ei voida tarkastella yksilön ja hänen sosiaalisten olosuhteidensa välistä vuorovaikutusta (Archer 2000, 2003). Emirbayer ja Mische (1998) ovat kritisoineet ajalli- sen ulottuvuuden puuttumista Giddensin toimijuuskäsityksestä. He ehdottavat ajallisen perspektiivin laajentamista siten, että se kattaisi nykyisyyden lisäksi menneisyyden ja tulevaisuuden.

Giddensin teorian vahvuutena työelämätutkimuksen näkökulmasta on sen valtaa koskeva analyysi. Valta on toimijuuden oleellinen edellytys siinä mielessä, että saadakseen aikaan jotakin yksilö tarvitsee valtaa (power to), ja vallan puute merkitsee toimijuuden puuttumista. Vaikka viralliset ja epäviralliset valtasuhteet ovat olennainen osa työpaikkojen todellisuutta ja työssä oppimista, valtaa ei ole empiirisesti juurikaan oppimistutkimuksessa tarkasteltu. Koska valta monella tapaa sekä rajoittaa että resursoi työpaikkojen todellisuutta ja niissä harjoitettavaa toimijuutta, vallan rakenteet (johtamiskäytännöissä, organisaatiorakenteissa, työpaikan hallitsevissa diskursseissa) ja sen eri muodot tulisi ottaa tarkastelun kohteeksi erityisesti ammatillisen toimijuuden kohdalla (vrt. Eteläpelto ym. 2011).

Giddensin teoriaa on kritisoinut etenkin brittisosiologi Margaret Archer, jonka kriittiseen realismiin perustuvaa teoriaa on viime aikoina käytetty lisääntyvästi esimerkiksi identiteetti- ja naistutkimuksen piirissä. Archerin $(2000,2003)$ toimijuutta koskeva teoria nojaa paljolti sosiaalista konstruktionismia koskevaan kritiikkiin. Archerin lähtökohtana on realistinen sosiaalinen teoria. Hänen mukaansa diskursiivisten todellisuussuhteiden lisäksi ihmisellä on myös praktinen ja kehollinen suhde todellisuuteen. Archer pitää ensisijaisena praktista suhdetta, jossa keskeiset laatumääreet koostuvat ihmisen kapasiteeteista ja kompetensseista. Keholliset todellisuussuhteet viittaavat ihmisen fyysiselle terveydelle ja hyvinvoinnille merkittäviin tekijöihin, jotka luovat perustan minuudelle ja persoonalliselle identiteetille.

Archerin toimijuutta koskevassa teoriassa keskustellaan laajasti identiteetin käsitteestä. Identiteetissä erotetaan sosiaalinen identiteetti (sosiaalisesti tuotetut käsitykset minuudesta), ja kehollinen minätunne, joka edustaa jatkuvuutta yksilön elämänhistoriassa. Archer (2003) painottaa persoonallista identiteettiä ja sen ensisijaisuutta sosiaaliseen identiteettiin nähden. Persoonallinen identiteetti rakentuu jatkuvasta emotionaalisesti värittyneestä sisäisestä keskustelus- 
ta ympäristön kanssa. Tämä keskustelu on yksilön ja sosiaalisen välistä vuoropuhelua. Toimijuuden Archer määrittelee intentionaaliseksi ja tavoitteelliseksi prosessiksi, jolla on suhteellinen autonomia henkilön minuuden harjoituksessa ja toteutuksessa. Nähdessään toimijuuden intentionaaliseksi Archer on samoilla linjoilla Giddensin kanssa. Sen sijaan heidän näkemyksensä ovat vastakkaisia siinä, miten he näkevät toimijuuden ontologian sekä sosiaalisen ja yksilöllisen välisen suhteen.

Ajatellen toimijuuden määrittelyä työssä Giddensin ja Archerin keskustelu antaa merkittäviä aineksia työn kontekstin, olosuhteiden ja valtarakenteiden sekä toimijuuden rajoitteiden ja resurssien ymmärtämiseen. Kuitenkaan se ei tarjoa käsitteellisiä välineitä, joiden avulla voitaisiin ymmärtää yksilöiden kehityksellisiä prosesseja ja ammatillisia identiteettejä, jotka ovat keskeisiä ammatillisessa kehittymisessä ja oppimisessa. Näihin liittyviä ilmiöitä on sen sijaan pohdittu naistutkimuksen piirissä käydyssä toimijuuskeskustelussa.

\section{JÄLKISTRUKTURALISTINEN NAISTUTKIMUS: TOIMIJUUS, DISKURSSIT JA SUBJEKTIT}

Feministisessä jälkistrukturalistisessa keskustelussa toimijuutta on pohdittu pitkään ja siitä on esitetty kiistanalaisia käsityksiä. Keskustelussa on tarkasteltu, miten kieli ja kielen käyttö rakentavat ja antavat merkityksiä todellisuudelle. Tässä viitekehyksessä työskentelevät kasvatustieteilijät (esim. St. Pierre 2000; Walkerdine 1990) ovat tutkineet, miten kieli ja puhetavat toimivat, ja miten ne rajoittavat tai synnyttävät tietyntyyppisiä subjektipositioita ja valtarakenteita, jotka ovat läsnä kaikessa vuorovaikutuksessa ja inhimillisessä elämässä. Tutkimus kohdistuu puhetapojen rakenteisiin, jotka nähdään historiallisesti ja sosiaalisesti muodostuneina lausumina, termeinä, luokituksina ja uskomuksina. Keskeisenä tutkimuksen kohteena on ollut se, miten puhetavat sijoittavat tietyt henkilöt subjekteiksi ja toiset objekteiksi (St. Pierre 2000). Puhetapoja ei nähdä pelkästään kieleen liittyvinä asioina, koska ne samalla jäsentävät ja tuottavat tapoja, joilla ihmiset toimivat maailmassa. Karkeasti jälkistrukturalistiset teoriat voidaan niiden toimijuutta koskevan ontologian ja yksilön roolia koskevan käsityksen mukaan jakaa kahteen luokkaan: vahvaan ja välittävään jälkistrukturalismiin.

Vahvan jälkistrukturalismin edustajat nojaavat Derridan tekstuaalisuuteen olettaen, että tekstien ulkopuolella ei ole mitään (St. Pierre 2000; Weedon 1987). Tästä seuraa, että myös subjektit nähdään fiktiivisinä prosesseina, jotka ovat olemassa vain mielikuvissa, metaforissa, tarinoissa ja muissa kielen olomuodoissa kuten persoonapronomineissa (Gordon 2005). Vahvassa jälkistrukturalismissa toimijuuden käsite nousee subjektin ja subjektiposition käsitteistä. Erilaisten diskurssien oletetaan tarjoavan erilaisia subjektipositioita, eikä subjekti suinkaan ole vapaa valitsemaan mitä haluaa. Yhtäältä subjekti nähdään alisteisena ja pakotettuna tiettyihin hallinnan tapoihin, jotka ovat olemassa diskursseissa. Toisaalta subjektit voivat ilmaista toimijuutta sikäli kun he uudelleen kirjoittavat aiempia diskursseja (St. Pierre 2000; Weedon 1987). Toimijuus ymmärretään näin kielen ja diskurssien tasolla sosiaalisena ja kollektiivisena ilmiönä.

Vahvan jälkistrukturalismin ansiona voidaan pitää sitä, että se on paljastanut aiemmin näkymättömäksi jääneitä diskursiivisia valtarakenteita. Samalla se on antanut käsitteellisiä välineitä ymmärtää toimijuuden rajoitteina ja resursseina olevaa epävirallista ja virallista valtaa, joka ilmenee työorganisaatioissa ja ammatillisissa ympäristöissä hegemonisina diskursseina (esim. Hökkä ym. 2012). Vahvaa jälkistrukturalismia on kuitenkin kritisoitu minuuden häivyttämisestä vahvojen rakenneteorioiden tapaan - vain sillä erotuksella, että rakenteet pelkistetään kieleksi ja diskurssiksi (McNay 2003). Jos subjektien ajatellaan rakentuvan ainoastaan diskursseissa, heille jää hyvin niukasti toimijuutta.

Kritiikki voimistui 2000-luvulla, jolloin joukko tutkijoita (The London Feminist Saloon Collective 2004) kyseenalaisti vahvan jälkistrukturalistisen käsityksen pitäen yksilön minuutta koskevaa käsitettä välttämättömänä. Vain tällä tavoin voitaisiin riittävästi ymmärtää yksilöllistä ja kollektiivista toimijuutta sekä niitä tapoja, joilla rakenne vaikuttaa toimijuuteen. Tässä voimme yhtyä kritiikkiin todeten, että identiteetin käsite on välttämätön tutkittaessa työhön liittyvää toimijuutta. Lisäksi pidämme tärkeänä, että toimijuutta 
ei nähdä pelkästään rationaalisena tai diskursiivisena ilmiönä, vaan siinä on aina mukana myös emotionaalinen puoli. Nämä eri puolet ovat mukana välittävän jälkistrukturalismin edustamassa käsityksessä toimijuudesta.

Vahvaan jälkistrukturalismiin kohdistuvassa kritiikissä on ehdotettu vaihtoehtoisia tapoja määritellä toimijuutta esimerkiksi Bourdieun habituskäsitteen pohjalta. McNayn (2004) mukaan toimijuus tulisi nähdä välittävänä tekijänä kulttuuristen ja taloudellisten voimien, identiteettien ja sosiaalisten rakenteiden välillä. Hänen mukaansa toimijuus viittaa yksilön kykyyn itsereflektioon ja itsearviointiin ja liittyy näin henkilön kokemuksiin maailmasta. Myös Clegg (2006) korostaa, että vahva jälkistrukturalismi ei kykene tarjoamaan käsitteellisiä välineitä yksilöllisen ja kollektiivisen toimijuuden ja minuuden käsitteellistämiseen. Hän ottaa episteemiseksi lähtökohdakseen Archerin kriittisen realismin ja kolmitasoisen todellisuussuhteen. Clegg pitää tältä pohjalta diskursiivista todellisuussuhdetta edeltäviä praktisia ja kehollisia suhteita välttämättöminä, jotta voitaisiin käsitteellistää inhimillistä toimijuutta ja minuuden rakentumista.

Toimijuuden käsite, sellaisena kuin McNay (2004) sen määrittelee, näyttäytyy välittävänä kategoriana, jonka kautta kulttuuristen ja taloudellisten voimien, identiteettien muokkauksen ja sosiaalisten rakenteiden välistä suhdetta voidaan tutkia ja ymmärtää. Välittävän jälkistrukturalismin käsitystä toimijuudesta voidaan pitää adekvaattina siinä, että se huomioi yksilön diskursiivisen todellisuussuhteen lisäksi myös praktisen ja kehollisen suhteen. Se ottaa huomioon yksilön tilannekohtaisen toiminnan näissä suhteissa samoin kuin yksilön toimintakapasiteetin, mukaan lukien itsereflektion ja itsearvioinnin. Lisäksi huomioidaan yksilön identiteetti ja nähdään sen yhteys toimijuuteen. Ammatillisen toimijuuden määrittelyyn liittyen oletamme samansuuntaisesti, että toimijuutta tulisi tutkia yksilön subjektikeskeisestä näkökulmasta siten, että huomioidaan yksilön kolmitasoiset suhteet todellisuuteen. Nämä on laiminlyöty - ei pelkästään vahvassa jälkistrukturalismissa - vaan myös sosiokulttuurisen lähestymistavan monissa suuntauksissa.
VILKASTUVA KESKUSTELU

\section{TOIMIJUUDESTA SOSIOKULTTUURISEN}

\section{LÄHESTYMISTAVAN PIIRISSÄ}

Sosiokulttuurisen lähestymistavan piirissä on hyvinkin poikkeavia käsityksiä siitä, miten sosiaalinen ja yksilöllinen ovat suhteessa toisiinsa. Näihin liittyen on myös erilaisia käsityksiä toimijuudesta. Erityisesti varhaisemmassa keskustelussa (karkeasti vuosina 1980-2000) yksilöllistä toimijuutta ei pelkästään jätetty huomiotta, vaan sen olemassaolo saatettiin eksplisiittisesti kieltää (esim. Roth 2007). Myöhemmin toimijuutta - ymmärrettynä etupäässä kollektiivisena ja sosiaalisena ilmiönä - on korostettu ja sitä on tutkittu runsaasti sosiokulttuurisen lähestymistavan piirissä (Billett 2006; Hökkä ym. 2012; Lasky 2005; Lipponen \& Kumpulainen 2011; Vähäsantanen ym. 2008).

Yhteistä sosiokulttuurisille lähestymistavoille on, että ne painottavat sosiokulttuurisen kontekstin, erityisesti työvälineiden ja työn kohteen merkitystä ihmisen toiminnan välittäjänä. Sosiokulttuurisen lähestymistavan sisällä on kuitenkin useita eri suuntauksia, jotka poikkeavat toisistaan siinä, missä määrin ne ottavat huomioon yksilökehitykselliset tekijät. Eroja on myös siinä, ymmärretäänkö yksilöllinen ja sosiaalinen analyyttisesti erilliseksi. Toisessa ääripäässä ( $\mathrm{mm}$. situationaalisen oppimisen ja jaetun kognition teoriat) oletetaan sosiaalisen kontekstin ja yksilön toiminnan olevan erottamattomia, jolloin ei analysoida erikseen yksilöllisiä prosesseja. Tässä sosiokulttuuriset tutkijat tulevat lähelle vahvaa jälkistrukturalismia siinä mielessä, että molemmat kieltävät yksilöllisen subjektin toimijuuden. Toisessa ääripäässä ovat kehityspsykologisesti suuntautuneet Vygotskin jalanjäljissä kulkevat tutkijat, jotka ovat todistelleet kielen ja teknologisten työkalujen välittävää roolia. Seuraavassa tehdään jako objektikeskeisiin teorioihin, joissa vallitsevana on työn kohteen ja työvälineiden korostus ja niihin, jotka edustavat subjektilähtöisiä kehityksellisiä suuntauksia.

Tyypillisenä objektikeskeisenä mallina voidaan pitää venäläisen psykologi A.N. Leontjevin (1987) toiminnan teoriaa. Siinä kuvataan toiminnan monitasoista luonnetta erottamalla toiminta, teko ja operaatio (Leontjev 1978). Objektikeskeiset lähestymis- 
tavat perustuvat marxilaiseen käsitykseen työstä heijastaen varhaisen teollisuustyön sidottua luonnetta, jossa ihminen oli lähinnä ulkoapäin ohjattu koneen osa. Teollisuuden liukuhihnalla työskentelevällä työntekijällä ei juuri ollut vapausasteita tehdä työssään yksilöllisiä valintoja, eikä yksilöllistä toimijuutta tässä mielessä tarvittu. Niinpä on ymmärrettävää, että työtoiminnan kuvauksessa korostuivat työn kohde ja työvälineet, kun taas työtä tekevä subjekti oli näille alisteinen ja näiden määrittämä.

Myöhemmät työssä oppimista kuvaavat teoriat poikkeavat toisistaan siinä, onko niissä lähtökohtana työkontekstista nousevat mallit vai yksilöllisiin ja sosiaalisiin oppimisprosesseihin liittyvät seikat. Ekspansiivisen oppimisen toimintateoreettinen malli (Engeström 1987) edustaa objektikeskeistä mallia, jonka painopiste on työn kohteessa ja työvälineissä. Objektikeskeisten lähestymistapojen pohjalta tehty empiirinen tutkimus on pyrkinyt osoittamaan, miten erilaiset työvälineet ja työn kohteen siirtymät välittävät ja rakentavat inhimilliselle toiminnalle keskeiset määreet.

Viime vuosina objektikeskeisen koulukunnan piirissä on käyty kriittistä keskustelua siitä, miten toiminnan kohde tulisi ymmärtää ja miten se tulisi erottaa esimerkiksi motiivin käsitteestä (Kaptelin \& Miettinen 2005). Joidenkin tulkintojen mukaan toiminnan kohde on ymmärretty mielikuvaksi konkreettisesta kohteesta, henkilön motiiviksi tai jopa halun kohteeksi (Kaptelin 2005). Toisissa tulkinnoissa objekti on nähty taloudellisiin, sosiaalisiin ja valtasuhteisiin kietoutuvana monimutkaisena ja vastakkaisia suhteita sisältävänä ilmiönä (Miettinen 2005). Stetsenko (2005) ehdottaa, että kulttuurihistoriallisen toiminnan teorian (CHAT) objektin käsitettä tulisi laajentaa käsittämään myös yksilösubjekti. Hänen mukaansa tulisi sovittaa yhteen ihmisen kehitystä koskeva ja sosiaalisten prosessien näkökulma sekä ymmärrys siitä, että ensisijaisesti yksilöllinen subjektius ja toimijuus mahdollistavat inhimillisen kehityksen ja sosiaaliset prosessit.

Vaihtoehtona vahvoille objektikeskeisille malleille sosiokulttuurisen lähestymistavan piirissä onkin lisääntyvästi tutkijoita, jotka tunnustavat työtä tekevän subjektin ja yksilöllisen toimijuuden merkityksen - kieltämättä kuitenkaan sosiaalisen, kulttuurisen ja

\section{HENKILÖN KÄSITYS}

\section{ITSEST $\ddot{A} \ddot{N}$ VAIKUTTAA}

\section{MYÖS MERKITT ̈̈V ̈̈STI}

\section{SIIHEN, MITEN JA}

\section{MILLAISTA TOIMIJUUTTA}

\section{HÄN HARJOITTAA.}

materiaalisen kontekstin merkitystä (Billett 2006; Eteläpelto 2008; Evans 2007; Hager 2011; Hodkinson, Biesta \& James 2008). Billett (2006) korostaa, että mikäli haluamme ymmärtää inhimillistä oppimista ja kulttuurin muuttumista, meidän tulisi kiinnittää huomiota yksilölliseen toimijuuteen, joka sisältää intentionaalisuuden, identiteetin ja subjektiuden. Billett pyrkii löytämään tasapainon sosiaalisen determinismin ja ääri-individualististen selitysmallien välille. Tässä hän nojaa malleihin, jotka kuvaavat yksilökehitystä (Cole 1996; Valsiner 1998) sekä yksilöllisen ja sosiaalisen vastavuoroista suhdetta (Archer 2000). Hän kuvaa yksilöllisen ja sosiaalisen suhdetta vahvasti toisistaan riippuvaksi. Yksilöt harjoittavat toimijuutta valitessaan millaisiin asioihin ja ongelmiin he tarttuvat, ja tällä on seuraamuksia siihen, mitä he oppivat ja miten he toimivat. Erilaisen osallisuuden ja kiinnittymisen seurauksena yksilöt oppivat erilaisia asioita (esim. Eteläpelto, Littleton, Lahti \& Wirtanen 2005).

Mitä tämä subjektilähtöinen painotus sitten merkitsee ammatillisen toimijuuden ja työssä oppimisen tutkimukselle? Ainakin se merkitsee tarvetta ottaa huomioon subjektien kiinnostukset ja identiteetit sen lisäksi, että huomioidaan sosiaalisten käytäntöjen historiallinen luonne, tavoitteet ja jatkumot sekä yksilöiden mahdollisuudet vaikuttaa näiden uudistamiseen. Edelleen tästä seuraa, että toimijuuden nähdään kietoutuvan subjektien ammatillisiin identiteetteihin ja työssä oppimiseen. Toimijuutta tarvitaan identiteettien muokkaamiseen ja uudelleenneuvotteluun. Henkilön käsitys itsestään vaikuttaa myös merkittävästi siihen, miten ja millaista toimijuutta hän harjoittaa. Tämän osoittaa myös laaja empiirinen tutkimus, jota on tehty Banduran sosiokogni- 
tiivisen minäpystyvyyttä koskevan teorian pohjalta. Heikko minäpystyvyys liittyy alhaiseen toimijuuteen ja korkea minäpystyvyys puolestaan aktiiviseen toimijuuteen, joka ymmärretään intentionaalisena vaikuttamisena omaan elämään ja elinoloihin (Bandura 2006).

Ammatillisen toimijuuden määrittelyä ajatellen näemme merkittävänä subjektilähtöisen lähestymistavan käsityksen, jonka mukaan ihmisten ajattelu, toiminta ja oppiminen ovat aina ikään kuin syvävärjäytyneet sekä määrittyneet ja tulleet resursoiduiksi heidän sosiokulttuurisen kontekstinsa mukaisesti. Oletamme myös, että sosiokulttuurisen kontekstin ja yksilöiden oppimisen sekä identiteettien rakentamisen välillä vallitsee vastavuoroisesti toisiaan rakentava suhde, jossa toimijuus näyttäytyy niin diskursiiviseen kuin praktiseen ja keholliseen todellisuussuhteeseen liittyvinä tekoina. Niinpä toimijuutta tulisikin analysoida tarkastelemalla sen ilmentymiä sekä 1) sosiokulttuurisessa ja diskursiivisessa todellisuudessa (kielessä, kulttuurisissa käytänteissä, sosiaalisissa normeissa, hegemonisissa diskursseissa sekä niihin liittyvissä virallisissa ja epävirallisissa valtasuhteissa) että 2) subjektien tulkinnoissa, ja merkityksenannoissa sekä siinä, miten nämä ovat kietoutuneet yksilöiden identiteetteihin. Koska toimijuus vaihtelee ajan ja olosuhteiden mukaan, toimijuutta tulisi tutkia ajallisesti vaihtelevana ilmiönä ihmisen elämänkulun perspektiivistä. Ajallinen ulottuvuus on paljolti laiminlyöty oppimisen tilannekohtaisuutta kuvaavissa malleissa. Sen sijaan ajallisuus on vahvasti läsnä toimijuutta elämänkulussa tarkastelevassa keskustelussa.

\section{TOIMIJUUS JA IDENTITEETIT \\ ELÄMÄNKULKUTUTKIMUKSESSA}

Elämänkulkututkimuksen perinteessä toimijuutta on tarkasteltu siitä näkökulmasta, miten yksilöt rakentavat elämänkulkuaan erilaisissa sosiaalisissa oloissa (Elder, Johnson \& Crosnoe 2003). Toimijuutta ilmentäviksi teoiksi ja valinnoiksi ymmärretään ne, jotka rakentavat yksilöiden elämänkulkuja. Sosiaaliset olosuhteet nähdään ihmisen toiminnasta analyyttisesti erillisinä samalla kun ne ymmärretään sosiaalisina ja historiallisina resursseina ja rajoitteina yksilöiden toiminnalle. Toimijuuden käsitteellistämiseen kuuluu vahvasti ajallinen ulottuvuus, joka viittaa yksilön elämänkulkuun.

Elämänkulkututkimuksen näkökulmasta toimijuuden ymmärtäminen erilaissa konteksteissa ja eri aikoina edellyttää huomion kiinnittämistä siihen dynaamiseen vuorovaikutukseen, joka vallitsee 1) menneisyydestä tulevien seuraamusten ja aiempien kokemusten, 2) nykyhetken tekojen ja 3) tulevaisuuteen suuntautuvien orientaatioiden kesken. Toimijuuden nähdään nousevan menneistä saavutuksista sekä niihin nojaavista käsityksistä ja toimintamalleista (Ecclestone 2007). Elämänkulkututkimuksen viitekehyksessä korostetaan voimakkaasti historiallisten ja sosiaalis-taloudellisten olosuhteiden merkitystä. Traditioon kuuluu tutkimusperinne, joka tarkastelee identiteettien, toimijuuden ja rakenteiden välisiä suhteita ja valottaa ihmisten 'elettyjä sosiaalisia realiteetteja' vallitsevien diskurssien ja käytäntöjen sisällä. Evans (2002) kehitti sidotun toimijuuden (bounded agency) käsitteen kuvaamaan sitä monimutkaista vuorovaikutusten kenttää, joka syntyy kulttuurisen kontekstin, instituutioiden, henkilöiden omien asenteiden ja tekojen yhteydestä työelämän, koulutuksen ja sosiaalisen tuen järjestelmiin (ks. Vanhalakka-Ruohon artikkeli tässä numerossa).

Hitlin ja Elder (2007) tekevät hyödyllisen erottelun 1) eksistentiaalisen, 2) pragmaattisen, 3 ) identiteettiin ja 4) elämänkulkuun liittyvän toimijuuden välille. Eksistentiaalinen toimijuus tarkoittaa ihmisen universaalia mahdollisuutta ja kapasiteettia itseohjautuvaan ja aloitteelliseen toimintaan. Pragmaattinen toimijuus ilmenee tekoina, joita tarvitaan silloin kun tottumukseen perustuvat rutiinit eivät riitä ja vaaditaan välitöntä muutosta toiminnan kulkuun tai aivan uudenlaista toimintaa. Identiteettitoimijuus viittaa identiteettisitoumuksiin, jotka motivoivat toimintaamme. Elämänkulkuun liittyvä toimijuus viittaa henkilön pyrkimykseen vaikuttaa omaan kehityskulkuunsa pitkällä tähtäimellä. Erityisesti elämänkulun siirtymissä ja käännekohdissa tehdyt päätökset kuvaavat tapoja, joiden kautta ihmiset ovat aktiivisia toimijoita muokatessaan elämäkulkuaan (Hitlin \& Elder 2007).

Määriteltäessä ammatillista toimijuutta työssä elämänkulkututkimukseen liittyvä toimijuuden kä- 
site tarjoaa hyödyllisiä aineksia subjektikeskeiselle sosiokulttuuriselle lähestymistavalle. Sen vahvuutena on elämänkulkuun liittyvän ajallisen ulottuvuuden huomioon ottaminen. Lisäksi se huomioi ihmisten identiteettisitoumusten merkityksen yksilöiden valintojen ja tekojen kannalta. Traditio tarjoaa hyödyllisiä käsitteellisiä välineitä, jotka kuvaavat, miten identiteetti on kietoutunut toimijuuden harjoittamiseen käytännön tilanteissa. Elämänkulkuun liittyvää toimijuutta tarvitsevat yhtä hyvin nuoret kuin aikuiset rakentaessaan elämänkulkuaan ja työuriaan monimutkaisessa ja epävarmassa todellisuudessa. Yksilöt joutuvat siinä tekemään päätöksiä, miten he rakentavat urapolkujaan koulutuksen ja työelämän sekä perhe-elämän ja yksilöllisten elämäntavoitteiden kentässä.

\section{TOIMIJUUSKÄSITYSTEN VERTAILUA JA YHTEENVETOA}

Taulukossa 1 on esitetty tutkimuskysymysten mukaisesti yhteenveto edellä tarkastelluista lähestymistavoista. Ensimmäinen tutkimuskysymys koski

\begin{tabular}{|c|c|c|c|}
\hline \multicolumn{2}{|l|}{ LÄHESTYMISTAPA } & \multirow{2}{*}{$\begin{array}{l}\text { ONTOLOGIA JA ILMENEMINEN } \\
\text { Toimijuus yksilöiden intentionaalisina ja rationaali- } \\
\text { sina tekoina, joilla on sosiaalisia seuraamuksia. } \\
\text { Temporaalisuutta ja identiteettejä ei tarkastella. }\end{array}$} & \multirow{2}{*}{$\begin{array}{l}\text { YKSILÖLLISEN JA SOSIAALISEN } \\
\text { VÄLINEN SUHDE } \\
\text { Erottamattomuus. } \\
\text { Analyyttisesti ensisijainen suunta } \\
\text { on yksilöstä sosiaaliseen (mikrosta } \\
\text { makroon). }\end{array}$} \\
\hline Sosiologinen & Giddens & & \\
\hline & Archer & $\begin{array}{l}\text { Sosiaalinen, praktinen ja luonnollinen todellisuus } \\
\text { ja ihmisen näitä vastaavat diskursiiviset, praktiset } \\
\text { ja keholliset suhteet maailmaan. } \\
\text { Agenttiset teot ovat intentionaalisia ja } \\
\text { tavoitteellisia prosesseja. } \\
\text { Persoonallinen identiteetti merkittävä. } \\
\text { Temporaalisuus huomioitu. }\end{array}$ & $\begin{array}{l}\text { Sosiaalinen ja yksilöllinen analyytti- } \\
\text { sesti erillisiä. } \\
\text { Sisäinen keskustelu ja emotionaalinen } \\
\text { elaborointi nähdään välittävinä proses- } \\
\text { seina yksilöllisen ja sosiaalisen välillä. }\end{array}$ \\
\hline \multirow[t]{2}{*}{$\begin{array}{l}\text { Jälkistruktura- } \\
\text { listinen naistut- } \\
\text { kimus }\end{array}$} & $\begin{array}{l}\text { Vahva jäl- } \\
\text { kistruk- } \\
\text { turalismi }\end{array}$ & $\begin{array}{l}\text { Toimijuus sosiaalisella ja kollektiivisella tasolla } \\
\text { diskursiivisena ilmiönä. } \\
\text { Toimijuus syntyy kun subjektipositioista käsin } \\
\text { kirjoitetaan uusiksi hegemonisia diskursseja. } \\
\text { Temporaalisuutta ja identiteettejä ei huomioida. }\end{array}$ & $\begin{array}{l}\text { Erottamattomuus: yksilöt pelkistetään } \\
\text { diskursseihin. } \\
\text { Diskursiivinen subjekti on alisteinen } \\
\text { vallitseville diskursseille. }\end{array}$ \\
\hline & $\begin{array}{l}\text { Välittävä } \\
\text { jälki- } \\
\text { struk- } \\
\text { turalismi }\end{array}$ & $\begin{array}{l}\text { Toimijuus ihmisten elettyinä kokemuksina sosiaa- } \\
\text { lisista suhteistaan ja kapasiteettina itsereflektioon } \\
\text { ja toimintaan. } \\
\text { Identiteetti ja subjektius keskiössä. } \\
\text { Temporaalisuutta ei tarkastella. }\end{array}$ & $\begin{array}{l}\text { Materiaalinen, kulttuurinen, taloudel- } \\
\text { linen sekä sosiaalinen analyyttisesti } \\
\text { erillisiä yksilöllisistä kokemuksista ja } \\
\text { identiteeteistä. } \\
\text { Toimijuus välittää yksilöllisen ja sosi- } \\
\text { aalisen suhdetta. }\end{array}$ \\
\hline \multirow[t]{2}{*}{$\begin{array}{l}\text { Sosiokulttuurinen } \\
\text { lähestymis-tapa }\end{array}$} & $\begin{array}{l}\text { Objekti- } \\
\text { keskeinen } \\
\text { toiminta- } \\
\text { teoria }\end{array}$ & $\begin{array}{l}\text { Prosessi-ontologia; yksilöllisen toimijuuden } \\
\text { hylkääminen ja/tai sen alisteisuus työn kohteelle } \\
\text { ja työvälineille. } \\
\text { Temporaalisuutta ei tarkastella. } \\
\text { Identiteetti ja subjektius kielletään. }\end{array}$ & $\begin{array}{l}\text { Yksilöllisen ja sosiaalisen erottamat- } \\
\text { tomuus. } \\
\text { Yksilöllisen redusointi sosiaalisiin } \\
\text { prosesseihin. }\end{array}$ \\
\hline & $\begin{array}{l}\text { Kehityk } \\
\text { sellinen } \\
\text { subjekti- } \\
\text { lähtöinen }\end{array}$ & $\begin{array}{l}\text { Yksilöt aktiivisina toimijoina suhteessa sosiaaliseen } \\
\text { maailmaan. Intentionaalisuus ja subjektius osalli- } \\
\text { suutena ja kiinnittymisenä. } \\
\text { Yksilökehityksellinen temporaalisuus sisältää elä- } \\
\text { mänhistorian ja aiemmat kokemukset. Identiteetti } \\
\text { huomioidaan. }\end{array}$ & $\begin{array}{l}\text { Analyyttisesti erillinen; keskinäinen } \\
\text { riippuvuus ja vastavuoroisuus yksilölli- } \\
\text { sen ja sosiaalisen välillä. } \\
\text { Toimijuus liittyy läheisesti henkilöiden } \\
\text { identiteetteihin. }\end{array}$ \\
\hline $\begin{array}{l}\text { Elämänkulku- } \\
\text { tutkimus }\end{array}$ & & $\begin{array}{l}\text { Yksilöiden tavat rakentaa omaa elämänkulkuaan } \\
\text { valintojen ja pitkän tähtäimen tekojen kautta. } \\
\text { Temporaalisuus huomioitu yksilöiden elämänkulun } \\
\text { mittakaavassa. } \\
\text { Identiteetit nostettu tarkastelun } \\
\text { keskiöön. }\end{array}$ & $\begin{array}{l}\text { Poissulkevasti erillinen: sosiaaliset ja } \\
\text { taloudelliset olosuhteet mahdollisuuk- } \\
\text { sina ja rajoitteina. } \\
\text { Historiallisesti muuttuvat ja kulttuuri- } \\
\text { sesti vaihtelevat elinolot. }\end{array}$ \\
\hline
\end{tabular}

Taulukko 1. Yhteenveto toimijuuskäsitysten ontologiasta sekä yksilöllisen ja sosiaalisen välisestä suhteesta. 
toimijuuden ontologiaa ja ilmenemismuotoja. Ontologisesti toimijuus on nähty kapeimmillaan vain yksittäisenä tavoitteellisena ja rationaalisena tekona. Laajimmillaan toimijuus on nähty sosiaalisesti ja diskursiivisesti rakentuvina subjektipositioina tai muuttuvina yksilöllisinä subjektiuksina ja identiteetteinä, jotka neuvotellaan sosiaalisten ja materiaalisten resurssien kentässä. Ontologisesti selkein jakolinja kulkee niiden toimijuuskäsitysten välillä, jotka näkevät toimijuuden pelkästään diskursiivisena ilmiönä (vahvat jälkistrukturalistit ja jotkut sosiokulttuurisen lähestymistavan edustajat) ja niiden välillä, jotka näkevät toimijuuden ilmenevän lisäksi ihmisen käytännöllisessä ja kehollisessa todellisuussuhteessa (esim. Archer 2003), jolloin siihen kuuluu myös esimerkiksi omaa hyvinvointia ja terveyttä koskeva ulottuvuus. Tällaisen kolmitasoisen todellisuussuhteen ovat omaksuneet myös välittävät jälkistrukturalistit (Clegg 2005, 2006; McNay 2003, 2004) painottaessaan toimijuuden praktista ja kehollista puolta, unohtamatta kuitenkaan diskursiivista tasoa.

Erot intentionaalisuuden ja temporaalisuuden osalta näkyvät siinä, että toimijuus on saatettu ymmärtää yksilön intentionaalisena valintana (esim. Giddens 1984) tai tälle vastakkaisesti henkilön elämänhistoriasta nousevana tapana rakentaa omaa elämänkulkuaan (esim. Hitlin \& Elder 2007). Aiemmin toimijuus ymmärrettiin usein ei-historiallisena ilmiönä, mutta viimeaikaisessa keskustelussa sitä on alettu tarkastella yhä enemmän ajallisena jatkumona, joka ulottuu nykyhetken yli menneisyydestä tulevaisuuteen (Emirbayer \& Mische 1998). Tämä on vaikuttanut siihen, että toimijuus liitetään yhä enemmän myös pitkän tähtäimen elämän tavoitteisiin. Ajallinen ulottuvuus on huomioitu ainoastaan niissä lähestymistavoissa, joissa on huomioitu myös yksilön identiteetti ja subjektius (välittävässä jälkistrukturalismissa, subjektikeskeisessä sosiokulttuurisessa ja elämänkulkututkimusta kuvaavissa lähestymistavoissa).

Ne lähestymistavat, jotka olettavat vain prosessien olemassaolon (erityisesti vahva jälkistrukturalismi ja objektikeskeinen sosiokulttuurinen lähestymistapa), ovat puutteellisia siten, että ne kieltävät toiminnan praktisen ja kehollisen puolen sekä yksilökehityksen tarkastelun. Sen sijaan praktinen ja kehollinen ulottuvuus ovat mukana välittävässä jälkistrukturalistisessa, kehityksellisessä sosiokulttuurisessa ja elämänkulkututkimuksen lähestymistavassa. Näiden lähestymistapojen ansiona onkin pidettävä sitä, että ne huomioivat ajallisen ja yksilön kehitykseen liittyvän ulottuvuuden.

Toiseen tutkimuskysymykseen liittyvä analyysi yksilöllisen ja sosiaalisen suhteesta osoitti, että eri lähestymistapojen välillä on huomattavia eroja siinä, miten tämä suhde ymmärretään. Käsitykset ulottuivat yksilön ja sosiaalisen erottamattomuutta koskevista käsityksistä analyyttiseen erottamiseen, jossa usein kuitenkin nähdään vahvaa keskinäistä riippuvuutta ja/tai vastavuoroisuutta. Niin sosiaalitieteissä kuin jälkistrukturalistisessa traditiossa on viime aikoina esitetty kasvavaa kritiikkiä erottamattomuusoletusta kohtaan. Kritiikki on kohdistunut siihen, että erottamattomuus estää kysymästä tärkeitä kysymyksiä yksilöllisen ja sosiaalisen välisestä suhteesta. Ellei sosiaalista ja yksilöllistä nähdä analyyttisesti erillisinä, ei voida myöskään kysyä, miten sosiaaliset, kulttuuriset ja materiaaliset olosuhteet vaikuttavat, rajoittavat ja/tai resursoivat yksilöllistä toimijuutta. Erottamattomuusoletuksella, joka samalla merkitsee prosessiontologiaa, onkin vakavia rajoituksia työn ja työhön liittyvän oppimisen tutkimuksessa. Se estää näkemästä ja asettamasta tärkeitä kysymyksiä niistä mekanismeista, jotka valitsevat sosiaalisten, kulttuuristen ja materiaalisten olosuhteiden ja yksilöllisen toimijuuden välillä. Se ei myöskään anna käsitteellisiä välineitä kysyä, miten nämä ovat yhteydessä ammatillisten identiteettien ja mielekkäiden elämänkulkujen rakentumiseen.

\section{SOSIOKULTTUURINEN SUBJEKTIKESKEINEN LÄHESTYMISTAPA AMMATILLISEEN TOIMIJUUTEEN}

Analyysimme pohjalta esitämme, että ammatillinen toimijuus tulisi käsitteellistää subjektikeskeisestä sosiokulttuurisesta lähestymistavasta käsin. Näkökulma kohdistaa huomion siihen, miten yksilöt rakentavat ammatillisia identiteettejään, ja miten he neuvottelevat toimijuutta rakentaessaan elämänkulkuaan ja työhistoriaansa vallitsevassa sosiaalisessa todellisuudessa, sen rajoitteissa ja resursseissa. 
TYÖPAIKAN

SOSIOKULTTUURISET

OLOSUHTEET

- Materiaaliset ehdot

- Fyysiset artefaktit

- Valtasuhteet

- Työkulttuurit

- Vallitsevat puhetavat
AMMATILLINEN TOIMIJUUS

Ilmenee, kun työntekijät ja/tai työyhteisöt vaikuttavat, tekevät valintoja ja ottavat kantaa niin, että he vaikuttavat työhönsä ja/tai ammatillisiin identiteetteihinsä.
AMMATILLISET

TOIMIJAT

- Ammatillinen identiteetti

- Ammatillinen osaaminen ja kompetenssit

- Työhistoria ja -kokemus

Kuvio 1. Subjektikeskeinen sosiokulttuurinen lähestymistapa ammatilliseen toimijuuteen.

Diskursiivisen todellisuussuhteen lisäksi tulisi huomioida myös praktiset ja keholliset suhteet. Pidämme tärkeänä sitä, että toimijuuden tutkimuksessa ei rajoituta pelkästään lyhytkestoisiin episodeihin ja poikkileikkaustutkimuksiin, vaan pyritään ymmärtämään toimijuutta elämänkulun ja yksilökehityksen perspektiivistä. Tällöin voidaan paremmin ymmärtää muun muassa sitä, miten ihmisten koulutuksen ja työn konteksteissa kehittyvät ammatilliset identiteetit ja työurat rakentuvat ja vaikuttavat toisiinsa. Kehityksellistä otetta tarvitaan myös, jotta voitaisiin ymmärtää oppimista, identiteettejä ja niiden kehittymistä silloin, kun henkilöt siirtyvät työstä ja työpaikasta toiseen, tai kun he navigoivat omaa polkuaan työelämän globaalisti määrittyvissä konteksteissa. Ilman tällaista toimijuuskäsitystä meiltä puuttuvat käsitteelliset välineet ymmärtää, miten ihmiset yhä epävakaammissa työelämän olosuhteissa rakentavat oman elämänsä jatkuvuuksia ja identiteettejä tai miten he luovasti muuttavat työkäytäntöjään, kulttuurejaan ja diskursseja työorganisaatioissa ja työyhteisöissä (Collin \& Billett 2010; Hökkä ym. 2010; Littleton, Taylor \& Eteläpelto 2012). Jos haluamme ymmärtää toimijuutta työelämän konteksteissa, meidän on tarkasteltava miten toimijuutta harjoitetaan, mikä sitä rajoittaa, mikä resursoi, ja miten se on sidottu kulloisiinkin kontekstitekijöihin kuten valtasuhteisiin ja diskursseihin, materiaalisiin ja sosiaalisiin olosuhteisiin ja sosiaalisen vuorovaikutuksen kulttuureihin työyhteisöissä (Kuvio 1).
Määrittelemme ammatillisen toimijuuden prosessiksi ja katsomme sen ilmenevän, kun työntekijät ja/tai työyhteisöt vaikuttavat, tekevät valintoja ja ottavat kantaa työhönsä ja ammatillisiin identiteetteihinsä. Subjektikeskeinen sosiokulttuurinen lähestymistapa hyödyntää aineksia niin sosiaalitieteellisestä ja välittävästä jälkistrukturalistisesta kuin subjektilähtöisestä sosiokulttuurisesta ja elämänkulkutoimijuuden traditioista. Oletamme, että ihmisellä on praktinen, diskursiivinen ja kehollinen suhde todellisuuteen, ja että toimijuus ilmenee ajallisesti muuttuvana yksilökehityksellisenä jatkumona, joka perustuu menneisyyteen, mutta sisältää aina myös tulevaisuusorientaation. Toimijuus on vahvasti kietoutunut persoonalliseen identiteettiin, jonka jatkuvuus näyttäytyy ja rakentuu ihmisten elettyinä ja kerrottuina kokemuksina ja tunteena omasta minuudesta. Sosiaalisen ja yksilöllisen suhteen näemme analyyttisesti erillisenä. Tämä mahdollistaa historiallisesti muuttuvan sosiaalisen ja yksilön ainutkertaisen elämänkulun vastavuoroisuuden tarkastelun. Toimijuutta ei tulisi kuitenkaan nähdä vain yksilöllisenä, vaan toimijuuden subjektina voi yhtä hyvin olla yhteisö (ks. Eteläpelto, Vähäsantanen, Hökkä \& Paloniemi 2013, 2014).

Subjektikeskeinen sosiokulttuurinen lähestymistapa ammatilliseen toimijuuteen voidaan tiivistää seuraavan seitsemän teesiin muotoon:

1) Ammatillinen toimijuus työssä merkitsee sitä, että ammatilliset subjektit ja/tai yhteisöt tekevät va- 
lintoja, käyttävät vaikutusmahdollisuuksiaan ja ottavat kantaa tavoilla, jotka vaikuttavat heidän työhönsä ja/tai ammatillisiin identiteetteihinsä.

2) Ammatillinen toimijuus kietoutuu työntekijän ammatilliseen identiteettiin (ammatilliset ja eettiset sitoumukset, ihanteet, motivaatiot, kiinnostukset, tavoitteet).

3) Työntekijöiden työhistoria ja -kokemus, osaaminen, asiantuntijuus ja kompetenssit toimivat heidän kehityksellisinä varantoinaan ja yksilöllisinä resursseinaan ammatilliselle toimijuudelle.

4) Ammatillisilla subjekteilla on diskursiivinen, praktinen ja kehollinen suhde (työn) todellisuuteen; nämä suhteet rakentuvat ajallisesti kattaen menneisyyden, nykyisyyden ja tulevaisuuden.

5) Ammatillista toimijuutta harjoitetaan aina tiettyä tarkoitusta varten ja tiettyjen historiallisesti muotoutuneiden työpaikan sosiokulttuuristen ja materiaalisten ehtojen sisällä; nämä sekä rajoittavat että resursoivat toimijuutta.

6) Ammatillista toimijuutta tarvitaan erityisesti oman työn ja työolojen (luovaan) kehittämiseen, työssä oppimiseen ja ammatillisen identiteetin neuvotteluun.

7) Ammatillisen toimijuuden tutkimuksessa yksilöllinen ja sosiaalinen on syytä nähdä analyyttisesti erillisinä ja toisiaan vastavuoroisesti rakentavina.

Työelämässä toimijuus näyttäytyy usein yhteisöllisenä ja kollektiivisena; tällöin toimijana on työyhteisö, tiimi, ammattijärjestö, osasto, työpaikka, organisaatio tai muu yhteenliittymä. Toimijuus voidaan työelämässä nähdä tavoitteena, jossa kohtaavat niin työntekijöiden vaikutusmahdollisuudet kuin työelämän muutosvaatimuksista nousevat uudistamistarpeet. Vaikutusmahdollisuudet luovat turvallisuutta ja hyvinvointia sekä mahdollisuuden kehittää omaa työtä samalla kun ne ylläpitävät ammatillisen toimijuuden edellytyksenä olevaa oman osaamisen vahvistamista sekä parantavat työn tuottavuutta ja laatua.

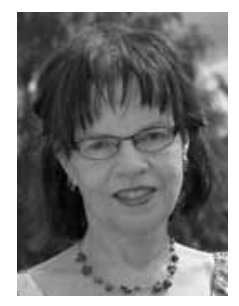

Anneli Eteläpelto

FT, professori

Kasvatustieteiden laitos Jyväskylän yliopisto

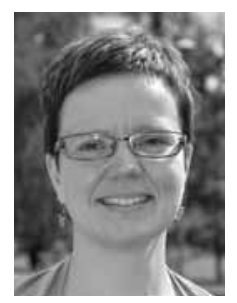

Katja Vähäsantanen

KT, tutkijatohtori Kasvatustieteiden laitos Jyväskylän yliopisto

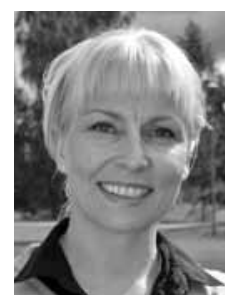

Päivi Hökkä

KT, projektitutkija Kasvatustieteiden laitos Jyväskylän yliopisto

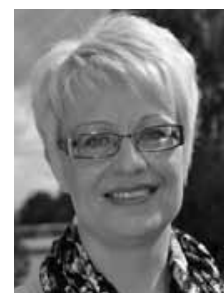

Susanna Paloniemi

$K T$, yliopistolehtori Kasvatustieteiden laitos Jyväskylän yliopisto 
Archer, M. (2000). Being Human: The Problem of Agency. Cambridge: Cambridge University Press.

Archer, M. (2003). Structure, Agency and the Internal Conversation. Cambridge: Cambridge University Press.

Bandura, A. (2006). Towards a psychology of human agency. Perspectives on Psychological Science, 1(2), 164-180.

Biesta, G., \& Tedder, M. (2007). Agency and learning in the life course: Towards an ecological perspective. Studies in the Education of Adults, 39(2), 132-149.

Billett, S., \& Pavlova, M. (2005). Learning through working life: Self and the individual's agentic action. International Journal of Lifelong Education, 24(3), 195-211.

Billett, S. (2006). Work, subjectivity and learning. Teoksessa Billett, S., Fenwick, T. \& Somerville, M. (toim.) Work, Subjectivity and Learning. Understanding Learning through Working Life. Dordrecht: Springer, 1-20.

Clegg, S. (2005). Theorising the mundane: The significance of agency. International Studies in Sociology of Education, 5(2), 149-163.

Clegg, S. (2006). The problem of agency in feminism: A critical realist approach. Gender and Education, 18(3), 309-324.

Cole, M. (1996). Cultural Psychology: A Once and Future Discipline. Cambridge: Harvard University Press.

Collin, K. \& Billett, S. (2010). Luovuus ja oppiminen työssä. Teoksessa Collin, K., Paloniemi, S., RaskuPuttonen, H. \& Tynjälä, P. (toim.) Luovuus, oppiminen ja asiantuntijuus. Helsinki: WSOY, 211-224.

Ecclestone, K. (2007). An identity crisis? The importance of understanding agency and identity in adults' learning. Studies in the Education of Adults, 39(2), 121-131.

Elder, G. H., Jr., Johnson, M. K. \& Crosnoe, R. (2003). The emergence and development of life course theory. Teoksessa Mortimer, J. T. \& Shanahan, M. J. (toim.) Handbook of the Life Course. New York: Kluwer, 3-19.

Emirbayer, M. \& Mische, A. (1998). What is agency? American Journal of Sociology, 103(4), 962-1023.

Engeström, Y. (1987). Learning by expanding. An activity - theoretical approach to developmental research. Helsinki: Orienta-Konsultit.

Eteläpelto, A. (2008). Perspectives, prospects and progress in work-related learning. Teoksessa Billett, S., Harteis, C. \& Eteläpelto, A. (toim.) Emerging Perspectives of Workplace Learning. Rotterdam: Sense, 233-247.
Eteläpelto, A., Heiskanen, T. \& Collin, K. (toim.) (2011). Valta ja toimijuus aikuiskasvatuksessa. Aikuiskasvatuksen vuosikirja 49. Helsinki: Kansanvalistusseura.

Eteläpelto, A., Littleton, K., Lahti, J. \& Wirtanen, S. (2005). Students' accounts of their participation in an intensive long-term learning community. International Journal of Educational Research, 43(3), 183-207.

Eteläpelto, A., Vähäsantanen, K., Hökkä, P. \& Paloniemi, S. (2013). What is agency? Conceptualizing professional agency at work. Educational Research Review, 10, 45-65.

Eteläpelto, A., Vähäsantanen, K., Hökkä, P. \& Paloniemi, S. (2014). Identity and agency in professional learning. Teoksessa Billett, S., Harteis, C. \& Gruber, H. (toim.) International Handbook of Research in Professional and Practice-based Learning, Vol. 2 Dortrecht: Springer. 645-672.

Evans, K. (2002). Taking control of their lives? Agency in young adult transitions in England and the new Germany. Journal of Youth Studies, 5(3), 245-269.

Evans, K. (2007). Concepts of bounded agency in education, work and the personal lives of young adults. International Journal of Psychology, 42(2), 85-93.

Fenwick, T. (2006). Escaping/becoming subjects: Learning to work the boundaries in a boundaryless work. In Billett, S., Fenwick, T. \& Somerville, M. (toim.), Work, subjectivity and learning. Understanding learning through working life, 21-36. Dordrecht: Springer.

Giddens, A. (1984). The Constitution of Society. Berkeley: University of California Press.

Gordon, T. (2005). Toimijuuden käsitteen dilemmoja. Teoksessa Meurman-Solin, A. \& Pyysiäinen, I. (toim.) Ihmistieteet tänään. Helsinki: Gaudeamus, 114-130.

Hager, P. (2011). Theories of workplace learning. Teoksessa Malloch, M., Cairns, L., Evans, K. \& O'Connor, B. N. (toim.) The Sage Handbook of Workplace Learning. Lontoo: Sage, 17-31.

Hitlin, S. \& Elder, G. H. (2007). Time, self and the curiously abstract concept of agency. Sociological Theory, 25(2), 170-191.

Hodkinson, P., Biesta, T. \& James, D. (2008). Understanding learning culturally: Overcoming the dualism between social and individual views of learning. Vocations and Learning: Studies in Vocational and Professional Education, 1(1), 27-47. 
Hökkä, P., Eteläpelto, A. \& Rasku-Puttonen, H. (2010). Recent tensions and challenges in teacher education as manifested in curriculum discourse. Teaching and Teacher Education, 26(4), 845-853.

Hökkä, P., Eteläpelto, A. \& Rasku-Puttonen, H. (2012). The professional agency of teacher educators amid academic discourses. Journal of Education for Teaching, 38(1), 83-102.

Kaptelin, V. (2005). The object of activity: Making sense of the sense-maker. Mind, Culture, and Activity, 12(1), 4-18.

Kaptelin, V. \& Miettinen, R. (2005). Perspectives on the object of activity. Mind, Culture, and Activity, 12(1), 1-3.

Lasky, S. (2005). A sociocultural approach to understanding teacher identity, agency and professional vulnerability in a context of secondary school reform. Teaching and Teacher Education, 21(8), 899-916.

Leontjev, A. N. (1978). Activity, Consciousness, and Personality. Englewood Cliffs, NJ: Prentice Hall.

Lipponen, L. \& Kumpulainen, K. (2011). Acting as accountable authors: Creating interactional spaces for agency work in teacher education. Teaching and Teacher Education, 27(5), 812-819.

Littleton, K., Taylor, S. \& Eteläpelto, A. (2012). Special issue introduction: Creativity and creative work in contemporary working contexts. Vocations and Learning Studies in Vocational and Professional Education, 5(1), 1-4.

McNay, I. (2003). Agency, anticipation and indeterminacy in feminist theory. Feminist Theory, 4(2), 139-148.

McNay, L. (2004). Agency and experience: Gender as a lived relation. The Sociological Review, 52(2), 173-190.

Miettinen, R. (2005). Object of activity and individual motivation. Mind, Culture, and Activity, 12(1), 52-69.

Packer, M. J., \& Goicoechea, J. (2000). Sociocultural and constructivist theories of learning: Ontology, not just epistemology. Educational Psychologist, 35(4), 227-241.

Paloniemi, S., \& Collin, K. (2012). Discursive power and creativity in inter-professional work. Vocations and Learning, 5(1), 23-40.

Roth, W. M. (2007). On the subject, self, and individual or monolingualism of the other and the possible impossibility of babel fish. Mind, Culture, and Activity, 14(4), 227-234.
Stetsenko, A. (2005). Activity as object-related: Resolving the dichotomy of individual and collective planes of activity. Mind, Culture, and Activity, 12(1), 70-88

St. Pierre, E. A. (2000). Poststructural feminism in education: An overview. Qualitative Studies in Education, 13(5), 477-515.

The London Feminist Salon Collective. (2004). The problematization of agency in postmodern theory: As feminist educational researchers, where do we go from here? Gender and Education, 16(1), 25-34.

Valsiner, J. (1998). The Guided Mind: A Sociogenetic Approach to Personality. Cambridge, MA: Harvard University Press.

Vähäsantanen, K., \& Eteläpelto, A. (2009). Vocational teachers in the face of a major educational reform: Individual ways of negotiating professional identities. Journal of Education and Work, 22(1), 15-33.

Vähäsantanen, K., \& Eteläpelto, A. (2011). Vocational teachers' pathways in the course of a curriculum reform. Journal of Curriculum Studies, 43(3). 291-312.

Vähäsantanen, K., Hökkä, P., Eteläpelto, A., RaskuPuttonen, H. \& Littleton, K. (2008). Teachers professional identity negotiations in two different work organisations. Vocations and Learning: Studies in Vocational and Professional Education, 1(2), 131-148.

Walkerdine, V. (1990). Schoolgirl Fictions. Lontoo: Verso.

Weedon, C. (1987). Feminist Practice and Poststructuralist Theory. Oxford: Blackwell.

Wenger, E. (1998). Communities of practice: learning, meaning, and identity. New York: Cambridge University Press.

\section{VIITTEET}

1 Pohjana on ollut laajempi englanninkielinen artikkeli Eteläpelto, A., Vähäsantanen, K., Hökkä, P. \& Paloniemi, S. (2013). 